\title{
Apresentação Dossiê:
}

Educação e capitalismo no Brasil: temas clássicos e problemas atuais.

\section{Presentation Dossier:}

Education and capitalism in Brazil: classic themes and current problems.

\section{Dossier de presentación:}

\section{Educación y capitalismo en Brasil: temas clásicos y problemas actuales.}

Esquecer é algo que os seres humanos aprenderam a fazer para deixar para trás todas as dores as quais foram vítimas. No entanto, também é o mecanismo usado pelo capitalismo para naturalizar relações de opressão, violência e exploração. Em meio a atual pandemia da Covid-19, temos a urgência de lembrar. Lembrar das mortes causadas não só pelo vírus e pela pandemia, que poderia ser evitada com ciência e políticas públicas, mas também das causadas pela apropriação da riqueza de forma privada. Assim, cabe-nos lembrar que o conhecimento é um fundamental instrumento para a apreensão e transformação da realidade.

É nesse intuito que apresentamos o dossiê sobre "Educação e capitalismo no Brasil: temas clássicos e problemas atuais", na revista Labor. Nele, as discussões teóricas estão permeadas de vivências dos pesquisadores e trazem à tona uma série de elementos para uma atualização das discussões acerca da temática proposta. Estão presentes na edição que vocês têm acesso agora questões como a inserção do capitalismo brasileiro no sistema mundial; a contribuição do marxismo à educação; a formas de gestão do capital aplicadas às escolas; a relação do ensino médio com as exigências da forma capitalista de produção; estratégias de luta dos trabalhadores.

Sabe-se que o debate sobre a relação entre estrutura econômica e educação é bastante polêmica em âmbito acadêmico, principalmente se a perspectiva dos pesquisadores tiver como fundamento a materialidade das transformações sociais. Contudo, esse debate é urgente, na medida em que as Ciências Sociais são chamadas a dar explicações sobre as sucessivas crises presentes na contemporaneidade - econômica, social, sanitária, cultural, dentre outras. 
Dessa maneira, a produção científica a respeito da imbricação entre as formas de produção material e as formas de organização da educação ganham relevo. Muitas das propostas de intervenção política na realidade educacional se baseiam na ilusão de que é a consciência que determina o ser social. Aprendemos a duras penas que o contrário é o verdadeiro, ou seja, é o ser social que determina a consciência. Por isso, num momento da história em que a relações mercantis estão universalizadas e em que a individualidade desdobrada dessas trocas mercantis estão generalizadas, não é possível imaginar que os sujeitos produzidos por essa materialidade sejam altamente críticos e criativos. Portanto, para pensar a educação na atualidade é preciso descortinar as relações de produção da existência em todos seus aspectos materiais em âmbito planetário. Encontraremos assim as contradições imanentes ao sistema e poderemos desvendar os caminhos para a construção de um futuro sem exploração.

Daí a importância dos artigos presentes nesse dossiê, pois eles são frutos dos estudos de pesquisadores engajados no esforço de se apropriar do real em sua dinâmica contraditória, e em decorrência disso projetar o devir numa ótica de classe e transformadora. Tal mudança ocorrerá não por uma missão teleológica salvacionista, mas pela falta absoluta de alternativas dentro da ordem, tornando imprescindível que se construa o saber e a ação mudancista nos locais e com os sujeitos da transformação social. Para tanto, coloca-se a necessidade de uma construção coletiva, superando quaisquer ações individuais e fragmentadas, permitindo à classe vislumbrar para além da aparência cotidiana, tendo a consciência tanto das contradições que permeiam o capitalismo como da necessidade de transformá-lo radicalmente. Por isso, se faz necessário o ataque frontal às leituras reformistas/idealistas presentes em muitos espaços acadêmicos e de organização sindical e política. O dossiê cumpre em parte esse papel.

Por fim, sabe-se que para resistir aos atuais ataques a seus direitos e para avançar em direção a conquistas, é fundamental para os trabalhadores o conhecimento e a lembrança, tanto dos acertos como principalmente de nossos erros. Crítica e autocrítica são elementos incontornáveis de uma ciência e de uma política que permitam não apenas compreender a realidade, como transformá-la. 
Programa de Pós-graduação em Educação, Universidade Federal do Ceará

"Só quando transgrido alguma ordem o futuro se torna respirável".

Mari Benedetti.

Prof. Dr. Ricardo Scopel Velho

Prof. Dr. Michael Goulart da Silva

Organizadores do Dossiê

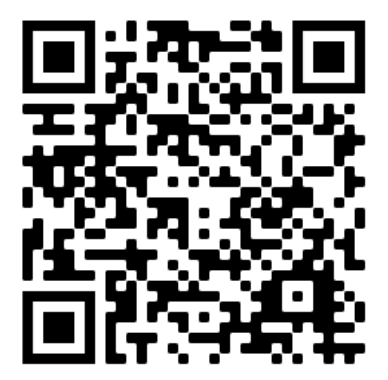

